\title{
Ecology of the spider crab Libinia ferreirae (Brachyura: Majoidea): ontogenetic shifts in habitat use
}

\author{
Geslaine Rafaela Lemos Gonçalves • Raphael Cezar Grabowski • Gabriel Lucas Bochini • \\ Rogerio Caetano da Costa $\cdot$ Antonio Leão Castilho
}

Received: 4 August 2016/Revised: 3 March 2017/ Accepted: 5 March 2017/Published online: 14 March 2017

(C) Springer International Publishing Switzerland 2017

\begin{abstract}
We described the ecology of the spider crab Libinia ferreirae testing the habitat segregation during the ontogenetic shifts. Collections were performed monthly by trawling along the coastal area of Cananéia, São Paulo State (southeastern Brazil). Medusae were examined for the presence of any symbionts, and crabs were classified as juveniles (abdomen sealed to the sternite), adults (unsealed abdomen), and ovigerous females (embryos adhered to the pleopods). The environmental factors related to the water column were obtained using a multiparameter probe. In total, 564 adults and 357 juveniles were collected. However, all juveniles were obtained in association with Lychnorhiza lucerna medusae. An increase in the abundance of ovigerous females was observed as chlorophyll levels (phytoplanktonic production) increased, which is consistent with the
\end{abstract}

Handling editor: Andrew Dzialowski

G. R. L. Gonçalves $(\bowtie) \cdot$ R. C. Grabowski ·

A. L. Castilho

Group of Studies on Crustacean Biology, Ecology and Culture (NEBECC), Zoology Department, Institute of Bioscience of Botucatu, São Paulo State University, São Paulo 18618-970, Brazil

e-mail: geslainelemos@yahoo.com.br

G. L. Bochini - R. C. da Costa

Laboratory of Biology and Ecology of Marine and Freshwater Shrimps (LABCAM), Biological Science Department, Faculty of Sciences of Bauru, São Paulo State University, São Paulo 17033-360, Brazil patterns proposed for crustaceans with planktotrophic larval stages, i.e., the association of larval hatching with oceanic productivity could explain the success in juvenile recruitment approximately two months after the peak in the abundance of ovigerous females (crosscorrelation: $r=0.96$ ). This spider crab shows an ecological strategy of habitat segregation among juvenile and adult individuals, thus avoiding competition for resources among different life cycle stages.

Keywords Association - Distribution - Effective spawning $\cdot$ Juvenile recruitment $\cdot$ Epibiont

\section{Introduction}

The timing and length of reproductive activities in crustaceans are strongly influenced by changes in environmental factors. For instance, chlorophyll content (phytoplanktonic productivity) is higher during periods with higher temperatures, thus increasing the density of food resources and consequently enhancing zooplankton abundance (Thorson, 1950). Phytoplankton are the main primary producers in coastal environments and are responsible for the onset of mass and energy flow through these trophic webs (Thorson, 1950; Vega-Perez, 1993). Therefore, they also contribute to the fertilization of such areas, which directly supports herbivorous taxa and indirectly supports animals in the higher levels of the trophic 
web (Dring, 1992). In addition to affecting the food supply, water temperature can also directly influence crustacean reproduction. Patterns of continuous reproduction are commonly observed in tropical species where constant temperatures are maintained throughout the year [e.g., the shrimp Xiphopenaeus kroyeri (Heller, 1862) and the crabs Persephona spp in Ubatuba bay $\left(23^{\circ} \mathrm{S}\right)$ (Almeida et al., 2013; Castilho et al., 2015)]. In contrast, seasonal reproductive patterns are generally observed in species from higher latitudes (temperate region), which are influenced by greater range environmental conditions (periodic or not) [e.g., the shrimp Sicyonia ingentis (Burkenroad, 1938) and the crab Cancer setosus Fabricius, 1798, respectively, in California $\left(34^{\circ} \mathrm{N}\right)$ and Chilean coasts $\left(41^{\circ} \mathrm{N}\right)$ (Anderson et al., 1985; Fischer \& Thatje, 2008)]. Thus, species adjust their life cycles to take advantage of periods with more favorable conditions to promote their development and survival (Sastry, 1983). However, the reproductive success of crustaceans can be evaluated by the occurrence of "effective spawning," which, as proposed by Crocos \& Van der Velde (1995), refers to situations in which a peak in the abundance of reproductive individuals is immediately followed by an observable peak in the number of juvenile individuals in subsequent months.

The spider crab, Libinia ferreirae Brito Capello 1871, is exclusively distributed in the western Atlantic Ocean (Costa Rica to Uruguay) from coastal areas up to depths of $35 \mathrm{~m}$, mainly in muddy bottoms (Melo, 1996; Tavares \& Santana, 2012). This Majoidea crab engages in symbiotic relationships throughout its lifespan. Megalopa larvae and juveniles associate with scyphozoan medusae, possibly enhancing the juvenile recruitment of these crustaceans by allowing them to move over a wide range while experiencing a lower predation rate (Gonçalves et al., 2016a). As adults, these crabs can host several epibionts (e.g., algae, sponges, and cnidarians), thereby expanding the distribution of these sessile organisms while gaining protection (camouflage) (Nogueira Jr. \& Haddad, 2005; Hultgren \& Stachowicz, 2011). L. ferreirae experiences heavy fishing pressure in both juvenile (=immature) stages, when it is captured inside its host medusae, and adult stages because it shares the same habitat as commercially targeted shrimp species (Schroeder et al., 2014; Branco et al., 2015). Fishing efforts on the Brazilian coast are directed toward the capture of numerous economically valuable shrimp species, especially X. kroyeri (D'Incao et al., 2002; Castilho et al., 2015), which has caused a rapid decline in shrimp stocks and the stocks of bycatch fauna and has led to significant losses of spawning biomass and biodiversity (Castilho et al., 2008a).

Studying the reproductive biology is fundamental to understanding the relationship between the reproductive and recruitment periods of certain species as well as their spawning processes and how particular environmental conditions influence these parameters (Castilho et al., 2008a; Varisco \& Vinuesa, 2011). The aim of this study was to describe the ecology of $L$. ferreirae in the region of Cananéia, São Paulo State (southeastern Brazil), by characterizing its reproductive periodicity, juvenile recruitment, sex ratio, and ecological distribution. We tested the hypothesis of habitat segregation of L. ferreirae during ontogenetic shifts, avoiding competition for resources among juvenile and adult stages.

\section{Materials and methods}

\section{Biological sampling}

Biological sampling was performed monthly at seven sampling stations by trawling for $30 \mathrm{~min}$ at each station. Trawls were conducted in the estuarine lagoon system of Cananéia-Iguape and its adjacent oceanic area (Fig. 1) using a shrimp fishing boat outfitted with double-rig nets from July 2012 through May 2014. However, individuals living in symbiosis with Lychnorhiza lucerna Haeckel, 1880, were identified from February 2013 through May 2014. Each medusa sampled by trawling was examined for the presence of crabs in the following body cavities: exumbrella, oral arms, oral pillars, gastric cavity, subgenital pouch, and gonads.

Sampled crabs were identified to species (Melo, 1996; Pohle et al., 1999; Tavares \& Santana, 2012) and sexed based on the shape of the abdomen (a thin shape for males and an oval shape for females) and the number of pleopods (two pairs for males and four pairs for females) (Ingle, 1977; Almeida et al., 2013). The carapace width $(\mathrm{CW})$ was measured using digital calipers (accuracy of $0.01 \mathrm{~mm}$ ), as the great distance between the spines of the lateral margin of the carapace, a microscope/stereoscope (Zeiss Stemi SV6) equipped with an image capture system (Zeiss 
Fig. 1 Sampling stations in the Cananéia region, São Paulo state, Brazil, where crabs were sampled
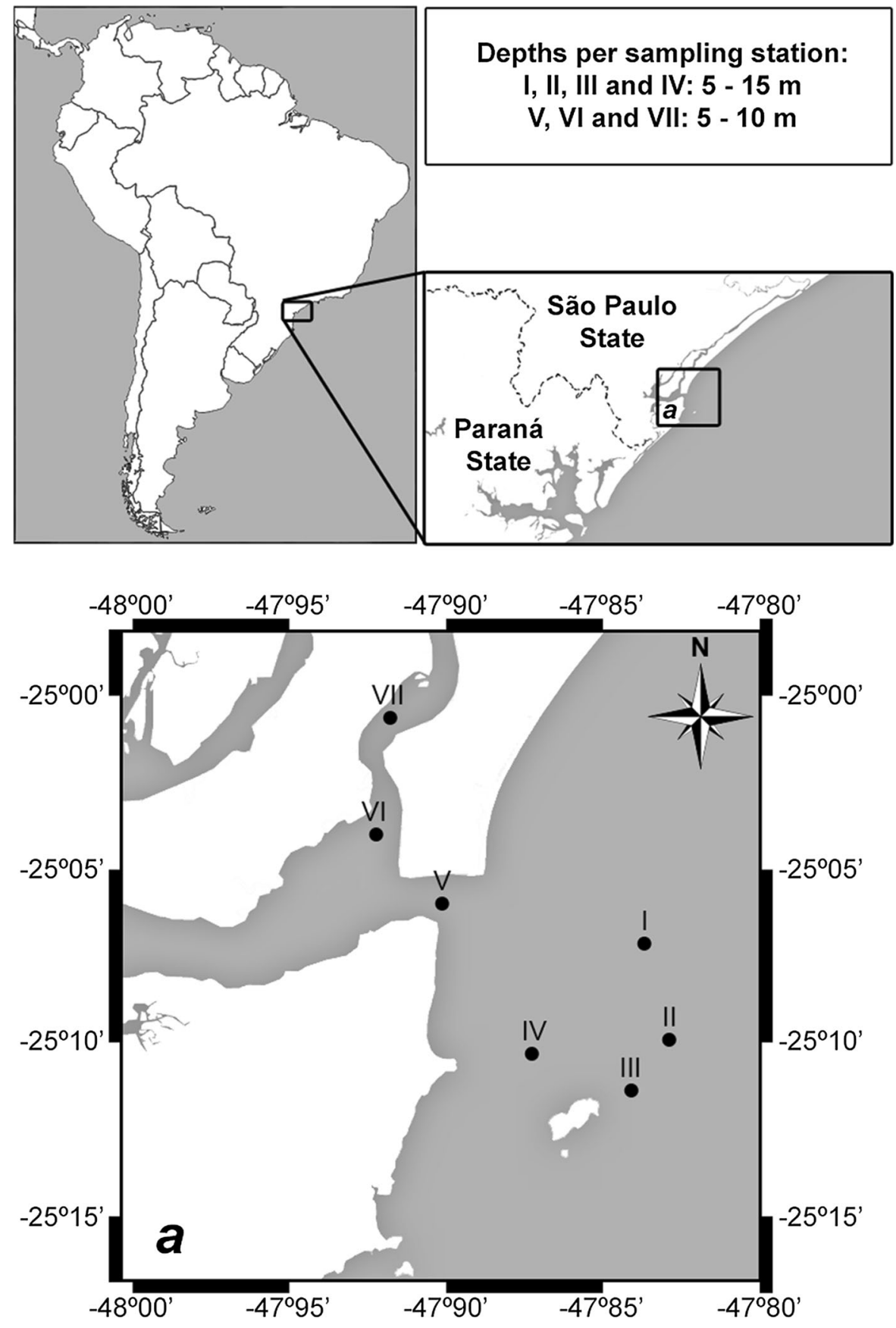

Reproductive aspects

Stemi 2000-C) (accuracy of $0.0001 \mathrm{~mm}$ ), was used to measure individuals with a $\mathrm{CW}<5 \mathrm{~mm}$. The abundances, as percentages, of ovigerous females (F OVG) and symbiotic juveniles were plotted according to their geographic coordinates in the region using Surfer software (version 8.0, Golden Software, California).
Individuals were classified as juveniles or adults based on the adherence of the abdomen to the cephalothoracic sternite; the abdomens of juveniles (unable to reproduce) were sealed to the sternite by a cementing 
substance (Bolla \& Negreiros-Fransozo, 2016). Alternatively, adults (able to reproduce) had an unsealed abdomen with no cementing substance (Haefner, 1990; Guinot \& Bouchard, 1998).

All crabs were submitted to a macroscopic examination of the gonads, and the stages of gonadal development were determined based on the shape, color and size of the ovaries, testicles and vas deferens (see: Choy, 1988; Abelló, 1989; Gonçalves et al., 2016a). Beyond the juvenile stage, two gonadal stages were differentiated in adult females: spent (SP) (thin and whitish-colored ovaries) and reproductive (RE) (with thicker and orange-colored ovaries). Similarly, the stages for adult males were spent (SP) (translucent and thin vas deferens) and reproductive (RE) (with a thicker and white-colored vas deferens [for more details, see Choy (1988) and Abelló (1989)]. Females carrying embryos (fertilized eggs) adhered to the pleopods (ovigerous females-OF) were described in posterior analyses.

\section{Environmental characterization}

Environmental factors related to the water column (temperature, salinity and chlorophyll) were measured using a EUREKA ${ }^{\circledR}$ multiparameter probe (Manta 2-4.0), for each month at each of the seven sampling stations throughout the entire study period; only the chlorophyll content of the water was analyzed over one year (January through December 2013).

Sediment samples were obtained during each season at all sampling stations using a Petersen grabber and were frozen until analysis in the laboratory. The samples were dried $\left(70^{\circ} \mathrm{C}\right.$ for $\left.72 \mathrm{~h}\right)$, and a 10 -g subsample from each sample was ash-weighted to determine the organic matter content (OM) of the substrate. Additionally, 100-g subsamples were used to determine the grain size based on the phi scale according to the methodology proposed by Hakanson \& Jansson (1983) and Tucker (1988) and adopted by Castilho et al. (2008b).

Grain size categories followed the American standard, i.e., sediments were sieved through $2 \mathrm{~mm}$ (gravel); 2.0-1.0 mm (very coarse sand); $1.0-0.5 \mathrm{~mm}$ (coarse sand); $0.5-0.25 \mathrm{~mm}$ (medium sand); $0.25-0.125 \mathrm{~mm}$ (fine sand); and 0.125-0.063 mm (very fine sand), and smaller particles were classified as silt-clay. Fractions were expressed on the phi $(\phi)$ scale, i.e., using the formula $\phi=-\log _{2} \mathrm{~d}$, where $d=$ grain diameter $(\mathrm{mm})$ (Tucker, 1988); e.g., $-1=\phi<0$ (very coarse sand); $0=\phi<1$ (coarse sand); $1=\phi<2$ (intermediate sand); $2=\phi<3$ (fine sand); $3=\phi<4$ (very fine sand), and $\phi \geq 4$ (silt + clay). Finally, $\phi$ was calculated using cumulative particle size curves that were plotted on a computer using the $\phi$ scale with values corresponding to the $16 \mathrm{th}$, 50th, and 84 th percentiles used to determine the mean diameter of the sediment according to the formula $\mathrm{Md}=\left(\phi_{16}+\phi_{50}+\phi_{84}\right) / 3$ (Hakanson \& Jansson, 1983; Tucker, 1988).

Statistical analysis

In this study, the number of crabs showed non-normal and non-homoscedastic distributions based on Shapiro-Wilk and Levene tests, respectively. Thus, differences in the abundance distributions of the crabs were tested by performing a Kruskal-Wallis test in each spatial and temporal scales, and for cases in which differences were observed between samples, a post hoc test (Student-Newman-Keuls method) was employed. Sex ratios were evaluated by a $\chi^{2}$ test.

The relationships between environmental factors (temperature, salinity, phi, and OM) and the abundances of adult females, ovigerous females, adult males, and juvenile individuals were evaluated using multivariate canonical correlation analysis (CANONICA), which directly measures the strength of the relationship between two sets of variables. The first set consists of the environmental conditions and the second of the abundance of each group of individuals. The values of the variables were transformed $(\log (1+x))$ prior to analysis, according to Castilho et al. (2008b).

To assess the time lag between spawning and juvenile recruitment, the temporal distribution of the ovigerous females was compared to that of the juveniles through temporal series analyses (crosscorrelations). Such analyses test for correlations in the data in the cause-effect intervals (lags) consisting of the three months prior to or after a given time point. Association coefficients between 0.99 and 0.7 were strong; those between 0.69 and 0.4 were moderate; and those between 0.4 and 0.1 were weak (for more details, see Castilho et al., 2015). For all of the statistical analyses performed in this study, we adopted a $5 \%$ level of significance (Zar, 1999). 


\section{Results}

Throughout the sampling period, we collected 921 spider crabs that, when separated by life stage, included 564 benthic (non-associated) individuals and 357 individuals living in association with $L$. lucerna. Peaks in the abundance of benthic individuals were recorded in September 2012 (winter) and January 2014 (summer). There were differences in the distribution of individuals throughout the studied months (Kruskal-Wallis: $H=37.1, P=0.02$ ), but the only months that differed significantly from each other were September 2012 and March 2012 (Fig. 2a). The highest density of collected specimens was recorded at sampling station I, and this value was significantly different from those of the other stations (KruskalWallis: $H=67.51, P=0.00$ ). The densities at sampling stations VI and VII were equal (Fig. 2b).

Crabs living in association with L. lucerna were more abundant in Mar/14 (summer), and this value was significantly different from those observed in the other months (Kruskal-Wallis: $H=38.1, \quad P=0.0009$, Fig. 2c). The highest abundance of such individuals was recorded at sampling station VI (Fig. 2d), although no statistically significant differences in abundance were observed among the sampling stations (KruskalWallis: $H=6.477, P=0.3719$ ).
The influence of environmental factors

We observed higher rates of capture of symbiotic individuals at temperatures between 25 and $28^{\circ} \mathrm{C}$ and at salinities between $30 \mathrm{ppt}$ and $34 \mathrm{ppt}$; benthic crabs were more abundant at temperatures between 28 and $31^{\circ} \mathrm{C}$ and salinities between $34 \mathrm{ppt}$ and $38 \mathrm{ppt}$. Benthic crabs were found in higher abundances at phi values $>3$ (mainly $>4$ ) and at $\mathrm{OM}$ values of $5-10 \%$ and 15-20\% (Fig. 3).

The analysis of the effects of environmental factors on the abundances of the different demographic groups (adult females, ovigerous females, adult males, and juveniles) revealed correlations among all of the factors and groups (CANONICA: $r=0.44, P=0.001)$ with a significant first canonical pair $(r=0.30, P=0.048)$. The canonical loadings (types of correlations among the variables) and the canonical weights (magnitudes of the relationships among the environmental factors and the biological data) are shown in Table 1. The environmental factors with the highest canonical loadings $(>0.5)$ were salinity $(-0.86)$ and phi $(-0.65)$, although only salinity had a high canonical weight $(-0.76)$. Ovigerous females were the only demographic group to show both a high canonical load $(-0.85)$ and weight $(-1.49)$.
Fig. 2 Monthly (a, c) and spatial (b, d) abundances of the spider crab Libinia ferreirae Brito Capello, 1871. a, b Number of benthic crabs; c, $\mathbf{d}$ number of individuals living in association with Lychnorhiza lucerna Haeckel, 1880. Bars with at least one similar letter did not show statistically significant difference (Student-Newman-Keuls Method, $P<0.05$ )

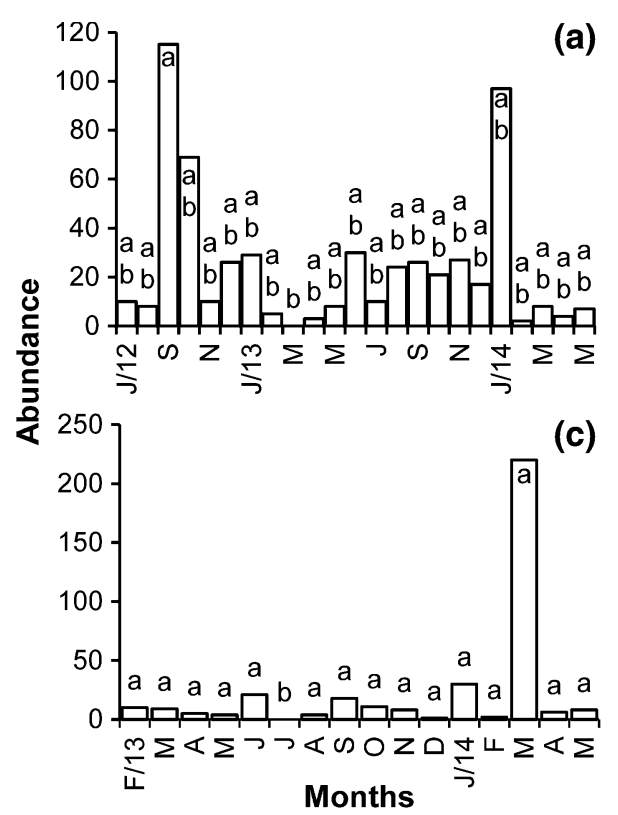

(b)
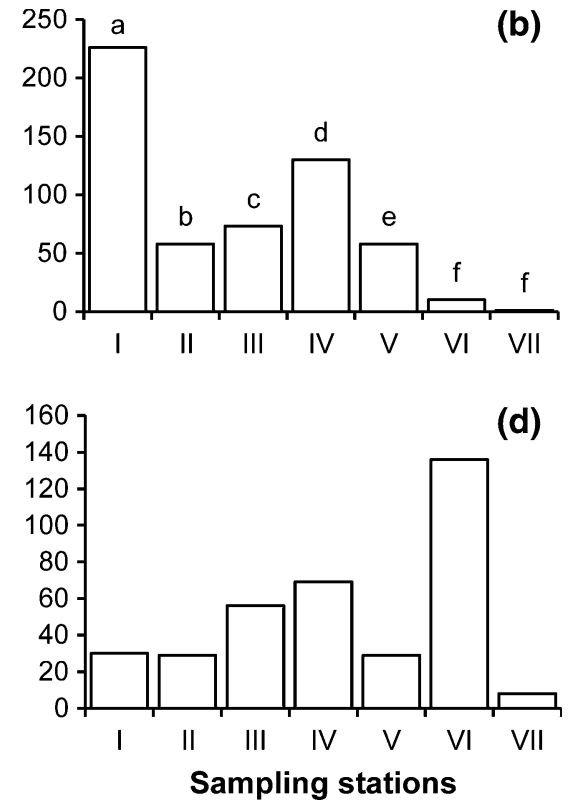

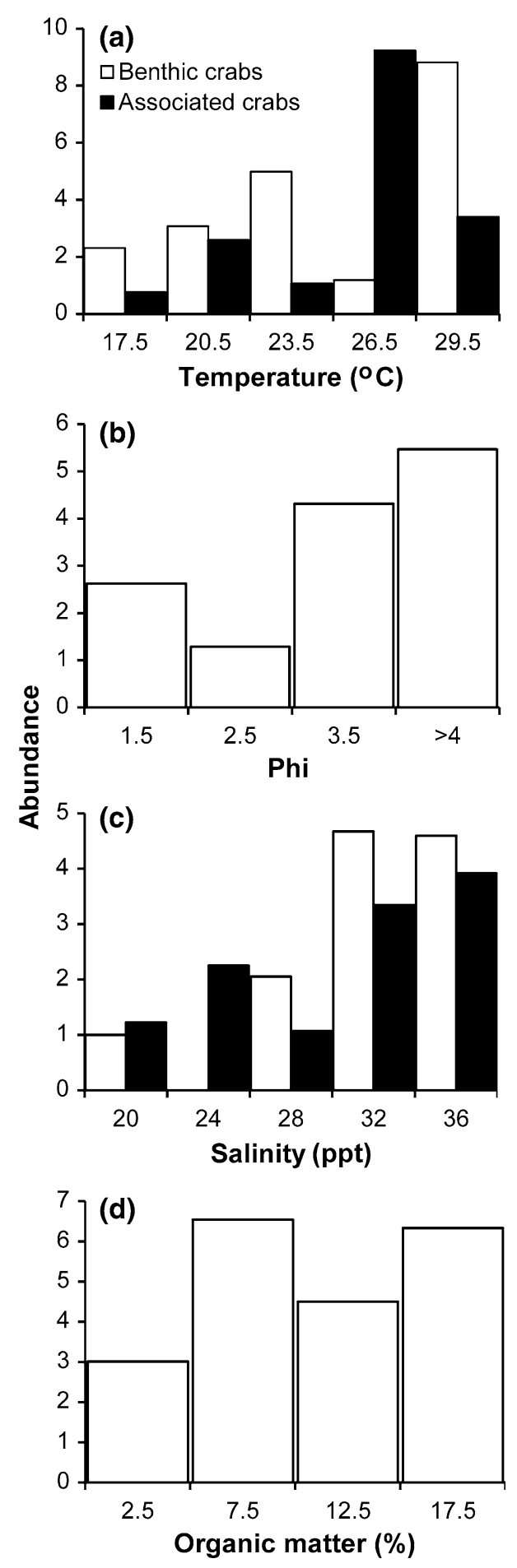

Reproductive biology

Of all sampled individuals, 786 were sexed, and there were 473 females $(51 \%)$ and 313 males $(34 \%)$. The
4Fig. 3 Variation in the mean abundance of the spider crab Libinia ferreirae Brito Capello, 1871. Abundance of benthic and symbiotic individuals, showing the catch per unit effort (CPUE) in terms of a bottom water temperature $\left({ }^{\circ} \mathrm{C}\right)$, $\mathbf{b}$ phi, $\mathbf{c}$ bottom water salinity (ppt), and $\mathbf{d}$ organic matter content $(\%)$. The values of the $X$-axis represent the midpoint of classes, i.e., temperature $17.5^{\circ} \mathrm{C}=16-18.9^{\circ} \mathrm{C}$, phi $1.5=1-1.9$, salinity $20=18-21.9$, organic matter $2.5=0-4.9 \%$

other 135 individuals could not be sexed due to their small size $(\mathrm{CW}<4 \mathrm{~mm})$ and the absence of visible secondary sexual characters. The adult individuals presented no evidence of a new molt below the existing carapace, thus indicating the possibility of determinant growth in this species.

Benthic crabs had sex ratio of 1:1.7 (M:F); the males constituted $37 \%$ of the population, demonstrating a significant difference in the abundances of the sexes $\left(\chi^{2}, P<0.001\right)$. This ratio persisted when the entire population was considered (benthic crabs + symbiotic crabs) with a 1:1.5 (M:F) sex ratio $\left(\chi^{2}, P<0.001\right)$, but there was no significant difference between the proportions of the sexes $\left(\chi^{2}, P>0.05\right)$ in symbiotic crabs alone (1:1.2, M:F).

The size of juvenile males varied from 4.2 to $44.3 \mathrm{~mm} \mathrm{CW}$, while the size of adult males varied from 30 to $78 \mathrm{~mm} \mathrm{CW}$. The smallest reproductive males had a mean size of $31.5 \mathrm{~mm} \mathrm{CW}$ (from 30 to $33 \mathrm{~mm} \mathrm{CW}$ ), suggesting that this size class represents the onset of physiological maturity, and all males larger than a mean size of $46.5 \mathrm{~mm}(45-48 \mathrm{~mm} \mathrm{CW})$ were physiologically adults. Males in the SP stage were represented by 106 individuals (31.83-77.84 $\mathrm{mm} \mathrm{CW}$ ), and there were 42 RE males (34-77.8 mm CW) (Fig. 4a). Among all of the collected males, only $13 \%$ were reproductive. There was no clear pattern of abundance and distribution of male crabs throughout the study period.

The size of juvenile females varied from 4.23 to $44.44 \mathrm{~mm} \mathrm{CW}$, while the variation in the size of adult females was from 30.2 to $71.6 \mathrm{~mm} \mathrm{CW}$. The mean size class of $46.5 \mathrm{~mm}(45-48 \mathrm{~mm} \mathrm{CW})$ exhibited the highest abundance, and this size class also had the highest abundance of ovigerous females. The largest ovigerous female had a CW of $71.64 \mathrm{~mm}$. There were 36 females in the SP stage (30.2-59.74 $\mathrm{mm} \mathrm{CW}), 36$ in the RE stage (38.9-59.4 mm CW), and $192 \mathrm{~F} \mathrm{OVG}$ individuals (38.08-71.64 mm CW) (Fig. 4b).

Ovigerous females were continuously present with peaks in January, June, August, September, and November 2013 and in January 2014, when we 
Table 1 Canonical loads and weights based on the analysis of canonical correlation between environmental factors and the abundance of demographic groups crabs (adult females, ovigerous females, adult males, and juvenile individuals)
Canonical load

Canonical weight

Environmental variables

Bottom temperature $\left({ }^{\circ} \mathrm{C}\right)$

0.23

0.27

Salinity (ppt)

$-0.86$

$-0.76$

Phi

$-0.66$

$-0.34$

Organic matter (\%)

$-0.46$

Biological data

Adult females

$-0.76$

0.19

Ovigerous females

$-0.85$

$-1.49$

Adult males

$-0.84$

$-0.15$

Juvenile individuals
$-0.32$

0.83

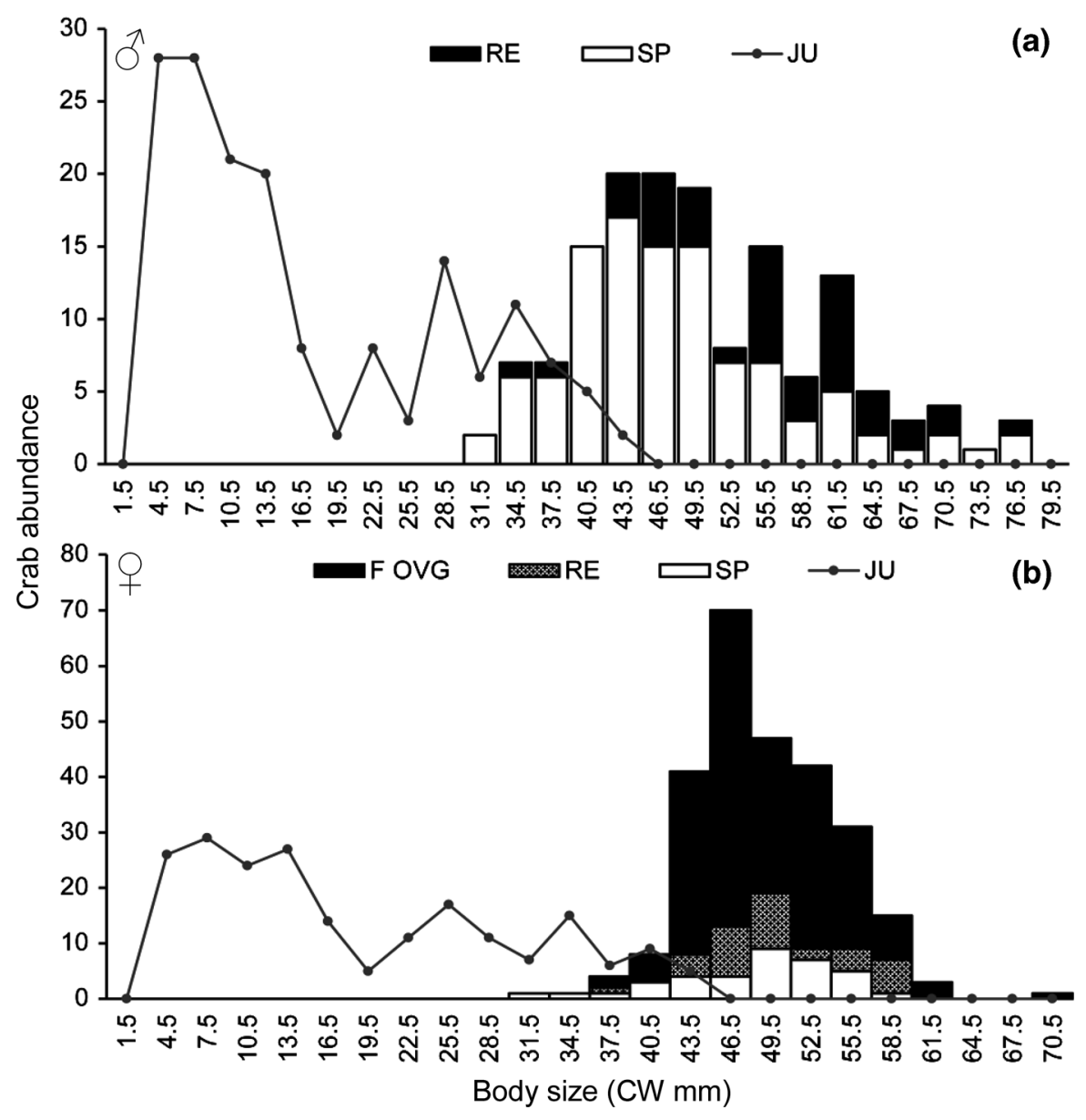

Fig. 4 Distribution of male (a) and female (b) of the spider crab Libinia ferreirae Brito Capello, 1871, in demographic groups ( $O V G$ ovigerous, $R E$ reproductive, $S P$ spent, $J U$ juvenile)

observed the greatest number of individuals during the study period (Fig. 5). Approximately $85 \%$ of the sampled ovigerous females presented developing or according to size classes for individuals sampled. The values of the $X$-axis represent the midpoint of size classes, i.e., $1.5 \mathrm{~mm}=0-3 \mathrm{~mm}$

developed gonads. Juvenile individuals showed two abundance peaks in September 2012 and March 2014, which were both preceded by peaks in the abundance 
Fig. 5 Monthly abundance of ovigerous females $(\mathrm{F}$ $\mathrm{OVG}$ ) and juvenile (JU) of the spider crab Libinia ferreirae Brito Capello, 1871, sampled

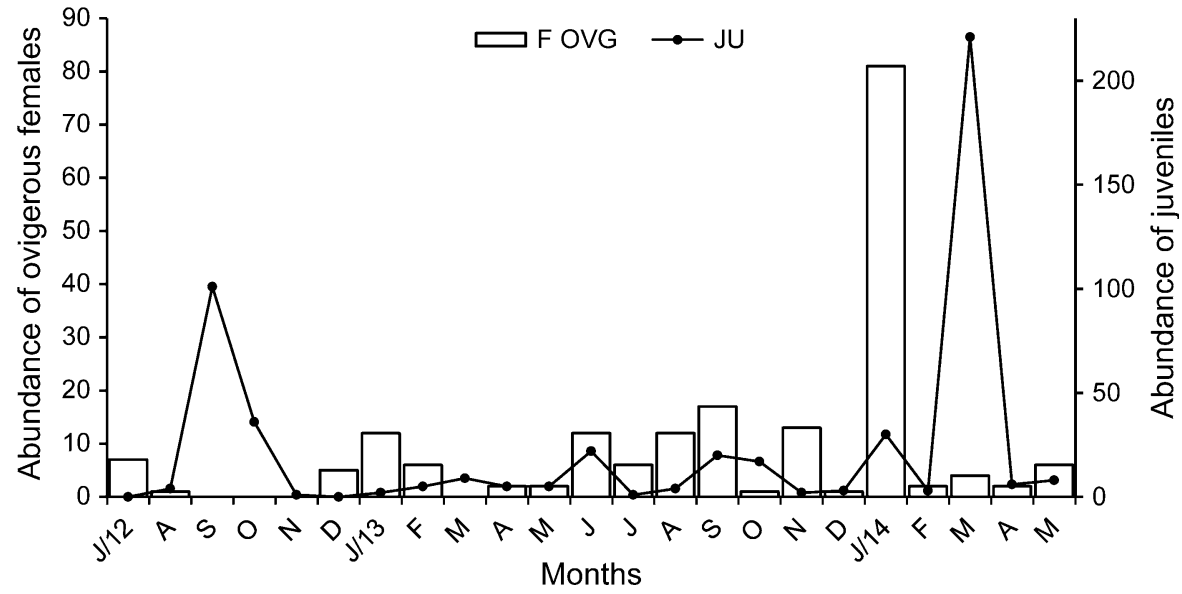

ovigerous females (January, June, September, and November 2013) preceded periods of peak phytoplankton production (March, July, October, and November 2013) (Fig. 7).

\section{Discussion}

Spatiotemporal distribution

Our study found variation in the spatiotemporal distribution of the spider crab population in the region of Cananéia, which is consistent with the results obtained for the congener species Libinia spinosa $\mathrm{H}$. Milne Edwards, 1834, in the southeastern Brazilian
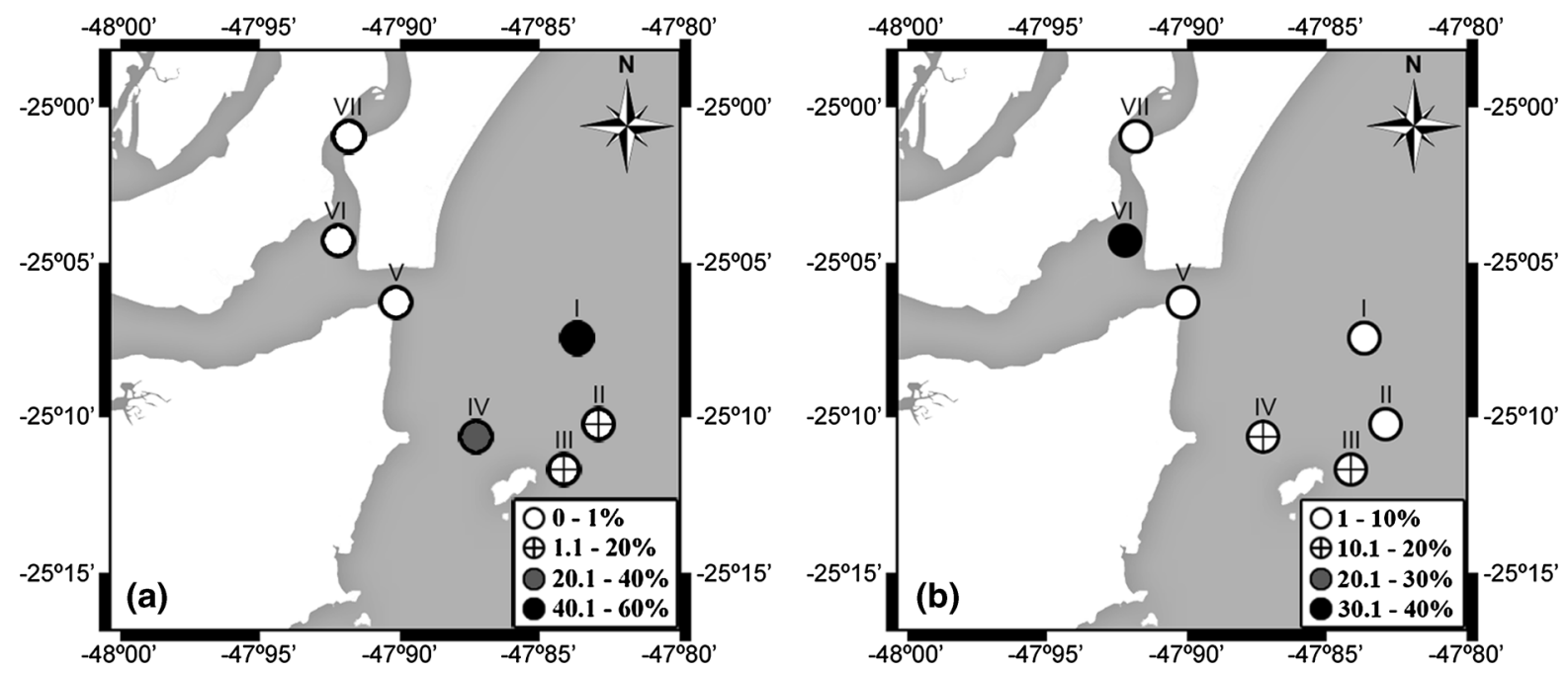

Fig. 6 Spatial variation in the abundance of ovigerous females (a) and spatial variation in the abundance of symbiotic juveniles (b) for spider crab Libinia ferreirae Brito Capello, 1871, sampled 


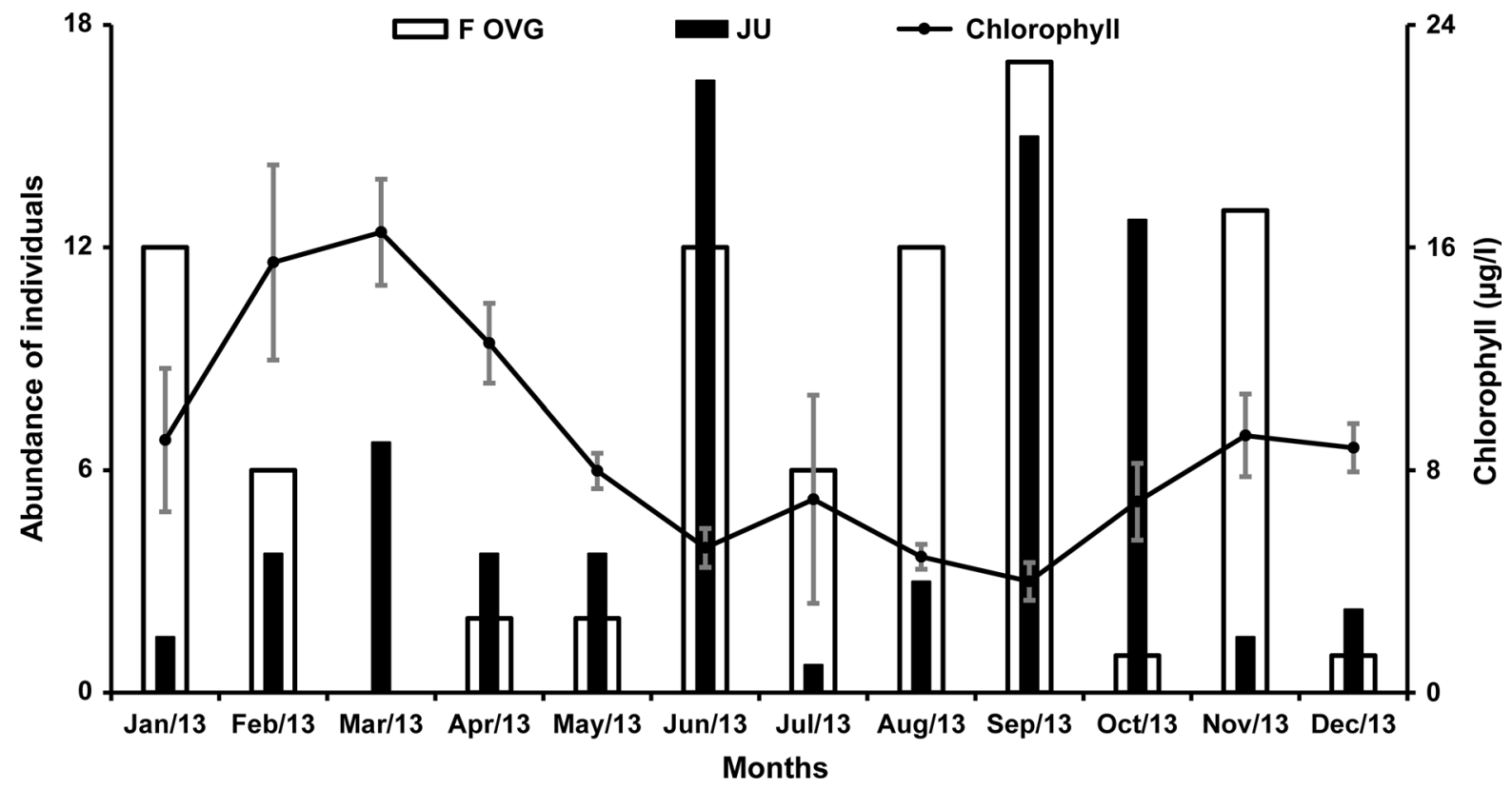

Fig. 7 Abundance of ovigerous females and juveniles to the crab Libinia ferreirae Brito Capello, 1871, and the average value of bottom water chlorophyll concentration $(\mu \mathrm{g} / \mathrm{l})$ sampled (spreads represent standard deviation)

littoral (Braga et al., 2007). We found clear shifts in habitat use of the species throughout its life cycle (from symbiotic juveniles to benthic adults). In terms of temporal distribution, Carmona-Suárez (2003) observed a similar pattern in Maja crispata Risso, 1827 , for which one of the highest peaks in the total abundance of benthic individuals was observed during winter, while the highest abundance of ovigerous females was observed during summer. Symbiotic (juvenile) crabs also presented a higher abundance in summer in our study. In accordance with the results of Anger (2001), there is a greater food supply and higher temperature levels in this period, which can accelerate larval hatching and thus shorten the duration of larval stages. Braga et al. (2007) also found a greater number of $L$. spinosa juveniles in summer and adults in winter in the region of Caraguatatuba, São Paulo.

The low abundance (or even the absence) of individuals in some months of the year was also observed by O'Brien et al. (1999) studying Libinia dubia H. Milne Edwards, 1834 and Libinia emarginata Leach, 1815. The latter authors propose that crabs can enter a state of dormancy or migrate to other areas during some periods of the year, while DeGoursey \& Auster (1992) observed that L. emarginata actually migrates to deeper waters during the winter, where individuals remain buried in the substrate until spring.
Similar mechanisms may help explain the low abundances of individuals during the autumn and winter. However, studies that consider a higher bathymetric amplitude are needed to confirm such migratory patterns.

In contrast to the pattern observed for symbiotic individuals, adult crabs were not commonly found at estuarine sampling stations, which suggests that juveniles and adults do not compete for environmental resources throughout their life cycle because they exhibit different life habits and requirements during their development and thus occupy different spaces over time (Dionne et al., 2003; Sforza et al., 2010). Thus, juveniles occupy host spaces (jellyfish) and thus occur in different places than adults because of their planktonic life stage (Nogueira Jr. \& Haddad, 2005; Sal Moyano et al., 2012).

The influence of environmental factors

The environment appeared to directly influence the life habits of L. ferreirae. Environmental features, such as water temperature, can alter crab development, mainly in terms of growth rate (Hartnoll, 1963; Petriella \& Boschi, 1997). The distribution pattern observed in this study allows us to infer that adult crabs are most likely to be found in areas with higher 
salinity and temperatures, so the variation in salinity likely drives the abundance of ovigerous females (the number of ovigerous females tended to increase as salinity increased). Studying Maja brachydactyla Balss, 1922, Rotllant et al. (2014) concluded that salinities higher than 38 ppt can drastically decrease larval survival and be a limiting factor in the life cycle of this species. Such intolerance to salinity was also observed in a congener species by Charmantier (1998), who showed that many Majoidea crabs, such as L. emarginata and Chionoecetes opilio (O. Fabricius, 1788), are weak regulators (or osmoconformers), which is an important factor in the settlement of many crustacean species. In contrast, the occurrence of symbiotic larvae and juveniles in areas with higher concentrations could be a consequence of the tide flows that carry the cnidarian hosts of the crabs to such habitats (Sal Moyano et al., 2012). Jellyfishes can withstand a wide salinity range (Schiariti et al., 2008), but their symbionts must tolerate this environment salinity.

Benthic crabs seem to show some preference for sediments composed mainly of silt + clay and very fine sand, as observed in L. spinosa in the Caraguatatuba region (Braga et al., 2007), so the great abundance of individuals (especially ovigerous females) observed at sampling station I (where the sediment was mainly composed of very fine sand) may be associated with the burrowing behavior of some majoidean crabs. For example, research by Winter \& Masunari (2006) stated that L. ferreirae spends most of its time buried in the sand, and only individuals with epizoic relationships have been observed emerging from the sediment. Ovigerous females are strongly influenced by sediment texture because they exhibited limited movement and must burrow to avoid predators (Winter \& Masunari, 2006). Additionally, females can use the nutrients found within the sediment as an alternative food source (Braga et al., 2007). Bas et al. (2007) in a study of a grapsoid crab, Chasmagnathus granulatus Dana, 1851, reported that environmental food availability was a key factor in egg production by females because food scarcity can considerably reduce fecundity.

\section{Reproductive biology}

Ovigerous females were collected during most of the studied months, and a large portion of them showed developing or even fully developed gonads in the process of generating a new embryo mass. GonzálezGurriarán et al. (1998) reported the same pattern for Maja squinado (Herbst, 1788); females with embryo masses in advanced stages of development (near larval hatching) exhibited mature ovaries. According to these authors, females of this species can copulate when eggs are still attached to their pleopods because their gonads are already developed and are capable of storing new spermatic masses. Thus, females can engage in up to four successive spawnings without copulating, as observed in C. opilio, the females of which can produce a new mass of eggs approximately three days after larval hatching (Elner \& Beninger, 1995).

Our study demonstrates that L. ferreirae presents a continuous reproductive pattern as observed for $L$. spinosa, which also occurs in a subtropical region (Braga et al., 2007). It is noteworthy that we observed a peak in the abundance of juveniles two months after a peak in ovigerous females, which is a pattern that characterizes continuous spawning (Crocos \& Van der Velde, 1995). The occurrence of juveniles was continuous even though the highest recruitment peak was observed in summer 2014 when higher temperature levels were recorded.

An increase in the abundance of ovigerous females was observed as chlorophyll levels (phytoplanktonic production) increased, which is consistent with the patterns proposed for crustaceans with planktotrophic larval stages. Because phytoplankton forms the base of the food web, serving as a food resource for innumerable species with larval stages, its presence triggers several stimuli that initiate the incubation of crab embryos and successive larval hatching (Starr et al., 1994; Elner \& Beninger, 1995). In the present study, we also observed that peaks in primary productivity were associated with periods of high temperatures, as observed by Vega-Perez (1993). The association of larval hatching with oceanic productivity could explain the success in juvenile recruitment approximately two months after the peak in the abundance of ovigerous females.

The onset of sexual maturity in both sexes is consistent with the results obtained by Sal Moyano et al. (2011) and Gonçalves et al. (2016b). The sizes of smaller male and female individuals in the SP stage were similar, although males in this phase exhibited a larger $\mathrm{CW}$ range. Males in the RE phase had smaller 
initial sizes than females, but their size range was greater, which was expected because males reach gonadal maturity at smaller sizes than females. The F OVG initiated at the smallest sizes in the RE range, reaching the size of the largest males (Gonçalves et al., 2016b). In our study, the adult size range was large, but Majoidea crabs have pre-pubertal and terminal molts (Hartnoll, 1963, 1982) that do not allow them to undergo successive growth molts when transitioning from the juvenile to adult stages. This would be an impediment to undergoing numerous molts after maturity, so the different sizes can be explained by genetic, food-related, and other factors (Hartnoll et al., 1993). A wide range of sizes have been observed in other studies, such for the genus Chionoecetes (Somerton, 1981; Comeau \& Conan, 1992), and these size differences may be a consequence of the age at sexual maturity or growth rates (González-Gurriarán et al., 1995). In majoidean crabs, the high variability in size at the onset of sexual maturity is a common phenomenon, especially in males, because the terminal molt can confer morphometric maturity (Hartnoll, 1963; Conan \& Comeau, 1986; Comeau \& Conan, 1992). According to Hartnoll et al. (1993) and González-Gurriarán et al. (1995), spatiotemporal differences in environmental conditions (especially temperature and food availability) can also influence individual growth rates, resulting in increases or decreases in the sizes of individuals.

The observed 1:1 (F:M) sex ratio in the early developmental stages in consistent with the results of Fisher (1930) because there is no agonistic behavior related to reproduction during these stages. However, it was possible to recognize a predominance of adult females relative to adult males. In contrast to the results obtained in this study, González-Pisani (2012) observed a 1:1 sex ratio in $L$. spinosa adults, and DeGoursey \& Auster (1992) found similar proportions in L. emarginata. The difference in the abundances of males and reproductive females observed in our study may be associated with the differences in environmental occupancy observed in each sex or with the constant rivalry between territorial and/or reproductive individuals, which could result in higher male mortality as stated by Hartnoll (1969). Additionally, males can have different distributions and occur in other regions that were not included in this study (Diesel, 1986).

\section{Conclusion}

We conclude that $L$. ferreirae completes its life cycle in the littoral adjacent to Cananéia because we sampled specimens of variable body sizes, life stages (i.e., juvenile, adult, and reproductive), and lifestyle habits (symbiotic and free-living crabs). Individuals living in association with medusae seem to be carried by their hosts into the estuarine environment and thus must tolerate wide variations in salinity and temperature. Sediment texture seems to directly influence the burrowing activity of ovigerous females that exhibited higher reproductive activity in the summer, during which we recorded effective spawning.

This study highlights the importance of preserving marine environments because L. ferreirae inhabits two different environments during its life cycle. We also observed differences in habitat occupation between juveniles and adults; L. ferreirae depends on jellyfish to successfully complete its ontogeny. The peculiarity of Cananéia region is a key factor in modeling the population dynamics of this species; if the environmental conditions do not favor development and reproduction or if there is great pressure from the fishing activity in a given area, the structure of a population can face collapse. The information presented here can be used as a basis for the management of coastal marine resources and for the preservation of bycaught species, which are also affected by fishing activities during their life cycle (e.g., L. ferreirae). Additionally, it is essential to conduct further studies focusing on aspects of community and behavior as well as ecological relationships and the influence of such parameters on the local ecosystem.

Acknowledgments The authors are indebted to "Fundação de Amparo à Pesquisa do Estado de São Paulo" (FAPESP) for providing financial support during field collections and visiting activities (Biota/FAPESP \#2010/50188-8 and Scholarship \#2014/ 13770-1), "Centro de Apoio Profissionalizante Educacional e Social" (CAPES CIMAR) (No. 23038.004310/2014-85), and to "Conselho Nacional de Desenvolvimento Científico e Tecnológico" (CNPq) (Financial Support \# 406006/2012-1, Research Scholarships PQ 303371/2011-0 and 308653/2014-9). We thank many colleagues from the "Núcleo de Estudos em Biologia, Ecologia e Cultivo de Crustáceos" (NEBECC) group who helped with sampling and laboratory analyses; Dr. Maria Lucia Negreiros-Fransozo for useful suggestions and comments on early drafts of the manuscript; and the "Instituto Brasileiro do Meio Ambiente e dos Recursos Naturais Renováveis" (IBAMA) for granting permission to collect the shrimps. 


\section{References}

Abelló, P., 1989. Reproduction and moulting in Liocarcinus depurator (Linnaeus, 1758) (Brachyura: Portunidae) in the northwestern Mediterranean. Scientia Marina 53: 127-134.

Almeida, A. C., C. M. Hiyodo, V. J. Cobo, G. Bertini, V. Fransozo \& G. M. Teixeira, 2013. Relative growth, sexual maturity, and breeding season of three species of the genus Persephona (Decapoda: Brachyura: Leucosiidae): a comparative study. Journal of the Marine Biological Association of the United Kingdom 93(6): 1581-1591.

Anderson, S. L., W. H. Clark \& E. S. Chang, 1985. Multiple spawning and molt synchrony in a free spawning shrimp (Sicyonia ingentis: Penaeoidea). The Biological Bulletin 168(3): 377-394.

Anger, K., 2001. The Biology of Decapod Crustacean larvae. Crustacean Issues 14, Balkema Lisse.

Bas, C. C., E. D. Spivak \& K. Anger, 2007. Seasonal and interpopulational variability in fecundity, egg size, and elemental composition (CHN) of eggs and larvae in a grapsoid crab, Chasmagnathus granulatus. Helgoland Marine Research 61: 225-237.

Bolla Jr., E. A. \& M. L. Negreiros-Fransozo, 2016. Morphology of juvenile phase of Achelous spinimanus (Latreille, 1819) (Crustacea, Decapoda, Portunidae) reared in laboratory. Journal of the Marine Biological Association of the United Kingdom 3: 615-631.

Branco, J. O., F. Freitas Jr. \& M. L. Christoffersen, 2015. Bycatch fauna of seabob shrimp trawl fisheries from Santa Catarina State, southern Brazil. Biota Neotropica 15(2): $1-14$.

Braga, A. A., A. Fransozo, G. Bertini \& P. B. Fumis, 2007. Bathymetric distribution and recruitment of the spider crab Libinia spinosa $\mathrm{H}$. Milne Edwards 1834 in the Ubatuba and Caraguatatuba regions, northern coast of São Paulo, Brazil (Crustacea, Brachyura, Majoidea, Pisidae). Senckenbergiana Biological 87(1): 7-16.

Carmona-Suárez, C. A., 2003. Reproductive biology and relative growth in the spider crab Maja crispata (Crustacea, Brachyura, Majidae). Scientia Marina 67(1): 75-80.

Castilho, A. L., R. C. Costa, A. Fransozo \& M. L. NegreirosFransozo, 2008a. Reproduction and recruitment of the South American red shrimp, Pleoticus muelleri (Crustacea: Solenoceridae), from the southeastern coast of Brazil. Marine Biology Research 4: 361-368.

Castilho, A. L., M. R. Pie, A. Fransozo, A. P. Pinheiro \& R. C. Costa, 2008b. The relationship between environmental variation and species abundance in shrimp community (Crustacea, Decapoda, Penaeoidea) in Southeastern Brazil. Journal of the Marine Biological Association of the United Kingdom 88: 119-123.

Castilho, A. L., R. T. Bauer, F. A. M. Freire, V. Fransozo, R. C. Costa, R. C. Grabowski \& A. Fransozo, 2015. Lifespan and reproductive dynamics of the commercially important sea bob shrimp Xiphopenaeus kroyeri (Penaeoidea): synthesis of a 5-year study. Journal of Crustacean Biology 35(1): 30-40.

Charmantier, G., 1998. Ontogeny of osmoregulation in crustaceans: a review. Invertebrate Reproduction Development 33: $177-190$.
Choy, S. C., 1988. Reproductive biology of Liocarcinus puber and L. holsatus (Decapoda, Brachyura, Portu-nidae) from the Grower Peninsula. South Wales. Marine Ecology 9: 227-291.

Comeau, M. \& G. Y. Conan, 1992. Morphometry and gonad maturity of male snow crab, Chionoecetes opilio. Canadian Journal of Fisheries and Aquatic Sciences 49: 2460-2468.

Conan, G. Y. \& M. Comeau, 1986. Functional maturity and terminal molt of male snow crab, Chionoecetes opilio. Canadian Journal of Fisheries and Aquatic Sciences 43: 1710-1719.

Crocos, P. J. \& T. D. Van Der Velde, 1995. Seasonal, spatial and interanual variability in the reproductive dynamics of the grooved tiger prawn Penaeus semisulcatus in Albatross bay, Gulf of Carpentaria, Australia: the concept of effective spawning. Marine Biology 122: 557-570.

D’Incao, F., H. Valentini \& L. F. Rodrigues, 2002. Avaliação da pesca de camarões nas regiões Sudeste e Sul do Brasil, 1965-1999. Atlântica 24(2): 103-116.

DeGoursey, R. E. \& P. J. Auster, 1992. A mating aggregation of the spider crab (Libinia emarginata). Journal of Northwest Atlantic Fishery Science 13: 77-82.

Diesel, R., 1986. Optimal mate searching strategy in the symbiotic spider crab Inachus phalangium (Decapoda). Ethology 72: 311-328.

Dionne, M., B. Sainte-Marie, E. Bourget \& D. Gilbert, 2003. Distribution and habitat selection of early benthic stages of snow crab Chionoecetes opilio. Marine Ecology Progress Series 259: 117-128.

Dring, M. J., 1992. The Biology of Marine Plants. Cambridge University Press, Cambridge.

Elner, R. W. \& P. G. Beninger, 1995. Multiple reproductive strategies in snow crab, Chionoecetes opilio: physiological pathways and behavioral plasticity. Journal of Experimental Marine Biology and Ecology 193: 93-112.

Fisher, R. A., 1930. The Genetical Theory of Natural Selection. Clarendon Press, Oxford.

Fischer, S. \& S. Thatje, 2008. Temperature-induced oviposition in the brachyuran crab Cancer setosus along a latitudinal cline: aquaria experiments and analysis of field-data. Journal of Experimental Marine Biology and Ecology 357: 157-164.

Gonçalves, G. R. L., E. B. Bolla Jr., M. L. Negreiros-Fransozo \& A. L. Castilho, 2016a. Morphometric and gonadal maturity of the spider crab Libinia ferreirae Brito Capello, 1871 (Decapoda: Majoidea: Epialtidae) at Southeastern Brazilian coast. Journal of the Marine Biological Association of the United Kingdom. doi:10.1017/S0025315416000370.

Gonçalves, G. R. L., M. R. Wolf, R. C. Costa \& A. L. Castilho, 2016b. Decapod crustacean associations with scyphozoan jellyfish (Rhizostomeae: Pelagiidae) in the Southeastern Brazilian coast. Symbiosis 69: 193-198.

González-Gurriarán, E., J. Freire, J. Parapar, M. P. Sampedro \& M. Urcera, 1995. Growth at moult and moulting seasonality of the spider crab, Maja squinado (Herbst) (Decapoda: Majidae) in experimental conditions: implications for juvenile life history. Journal of Experimental Marine Biology and Ecology 189: 183-203

González-Gurriarán, E., L. Fernández, J. Freire \& R. Muiño, 1998. Mating and role of seminal receptacles in the reproductive biology of the spider crab Maja squinado 
(Decapoda, Majidae). Journal of Experimental Marine Biology and Ecology 220(2): 269-285.

González-Pisani, X., Barón, P., \& L. S. López Greco, 2012. Functional anatomy of the female reproductive systems of two spider crabs (Decapoda, Majoidea). Invertebrate Biology 131(1): 61-74.

Guinot, D. \& J. M. Bouchard, 1998. Evolution of the abdominal holding systems of brachyuran crabs (Crustacea, Decapoda, Brachyura). Zoosystema 20: 613-694.

Haefner Jr., J. A., 1990. Morphometry and size at maturity of Callinectes ornatus (Brachyura, Portunidae) in Bermuda. Bulletin of Marine Science 46: 274-286.

Hakanson, L. \& M. Jansson, 1983. Principles of Lake Sedimentology. Springer, New York.

Hartnoll, R. G., 1963. The biology of Manx spider crabs. Proceedings of the Zoological Society of London 141: 423-496.

Hartnoll, R. G., 1969. Mating in the brachyura. Crustaceana 16: 161-181.

Hartnoll, R. G., 1982. Growth. In Bliss, D. E. (ed.), The Biology of Crustacea: Embryology, Morphology and Genetics. Academic Press, New York: 111-196.

Hartnoll, R. G., A. D. Bryant \& P. Gould, 1993. Size distribution in spider crab populations spatial and temporal variation. Journal Crustacean Biology 13(4): 647-655.

Hultgren, K. \& J. Stachowicz, 2011. Camouflage in decorator crabs. In Stevens, M. \& S. Merilaita (eds), Animal Camouflage: Mechanisms and Function. Cambridge University Press, Cambridge: 214-238.

Ingle, R. W., 1977. The larval and post-larval development of the scorpion spider crab, Inachus dorsettensis (Pennant) (family: Majidae), reared in the laboratory. Bulletin of the British Museum (Natural History): Zoology 30: 329-348.

Melo, G. A. S., 1996. Manual de identificação dos Brachyura (caranguejos e siris) do Litoral Brasileiro. Plêiade. FAPESP, São Paulo.

Nogueira Jr., M. \& M. A. Haddad, 2005. Lychnorhiza lucerna (Scyphozoa, Rhizostomeae) and Libinia ferreirae Brito Capello (Brachyura, Majidae) association in southern Brasil. Revista Brasileira de Zoologia 22: 908-912.

O’Brien, S. B., M. Landau \& K. W. Able, 1999. Sex ratios of two species of spider crabs, Libinia dubia H. Milne Edwards, 1834 and L. emarginata Leach, 1815: in the area of Great Bay. New Jersey. Crustaceana 72: 187-192.

Petriella, A. M. \& E. E. Boschi, 1997. Crecimiento en crustáceos decápodos: resultados de investigaciones realizadas en Argentina. Investigaciones Marinas 25: 135-157.

Pohle, G., F. L. Mantelatto, M. L. Negreiros-Fransozo \& A. Fransozo, 1999. Larval Decapoda (Brachyura). In Boltovskoy, D. (ed.), South Atlantic Zooplankton. Backhuys Publisher, Leiden: 1281-1351.

Rotllant, G., C. G. Simeó, G. Macià \& A. Estévez, 2014. High environmental salinity reduces the reproductive potential of the spider crab Maja brachydactyla (Decapoda, Majidae). Marine Ecology 36(3): 469-505.

Sal Moyano, M. P., M. A. Gavio \& M. D. Maggi, 2011. Morphometric and gonad maturity of the spider crab Libinia spinosa (Crustacea: Brachyura: Majoidea: Epialtidae) in Argentina. Journal of the Marine Biological Association of the United Kingdom 91: 837-844.

Sal Moyano, M. P., Schiariti, A., Gilberto. D. A., Diaz Briz, L., Gavio, M. A. \& H. W. Miazan, 2012. The symbiotic relationship between Lychnorhiza lucerna (Scyphozoa, Rhizostomeae) and Libinia spinosa (Decapoda, Epialtidae) in the Río de la Plata (Argentina-Uruguay). Marine Biology 159: 1933-1941.

Sastry, A. N., 1983. Ecological Aspects of Reproduction. In Vernberg, F. J. \& W. B. Vernberg (eds), The Biology of Crustacea. Environmental Adaptation. Academic Press, New York: 179-270.

Schiariti, A., M. Kawahara, S. Uye \& H. W. Mianzan, 2008. Life cycle of the jellyfish Lychnorhiza lucerna (Scyphozoa: Rhizostomeae). Marine Biology 156: 1-12.

Schroeder, R., J. O. Branco, F. Freitas Jr. \& C. Resgalla Jr., 2014. Preliminary assessment of the jellyfish bycatch captured off southern and southeastern Brazil. Latin American Journal of Aquatic Research 42: 289-300.

Sforza, R., R. C. Nalesso \& J. C. Joyeux, 2010. Distribution and population structure of Callinectes danae (Decapoda: Portunidae) in a tropical Brazilian estuary. Journal of Crustacean Biology 30: 597-606.

Somerton, D. A., 1981. Regional variation in the size of maturity of two species of tanner crab (Chionoecetes bairdi and C. opilio) in the eastern Bering Sea, and its use in defining management subareas. Canadian Journal of Fisheries and Aquatic Sciences 38: 163-174.

Starr, M., J. C. Theriault, G. Y. Conan, M. Comeau \& G. Robichaud, 1994. Larval release in a sub-euphotic zone invertebrate triggered by sinking phytoplankton particles. Journal of Plankton Research 16: 1137-1147.

Tavares, M. \& W. Santana, 2012. On the morphological differentiation between Libinia spinosa and L. ferreirae (Crustacea: Brachyura: Majoidea: Epialtidae). Zoologia (Curitiba) 29: 577-588.

Thorson, G., 1950. Reproductive and Larval Ecology of Marine Bottom Invertebrates. Zoological Museum, University of Copenhagen.

Tucker, M., 1988. Techniques in Sedimentology. Blackwell, Oxford.

Varisco, M. \& J. Vinuesa, 2011. Reproductive biology of the spider crab Leucippa pentagona (Decapoda: Epialtidae), in Bustamante Bay, Argentina. Revista de Investigaciones Marinas 39(3): 471-480.

Vega-Perez, L. A., 1993. Estudo do zooplâncton da região de Ubatuba, Estado de São Paulo. Publicação Especial do Instituto Oceanográfico 10: 65-84.

Winter, V. C. \& S. Masunari, 2006. Macroepizoismo em Libinia ferreirae (Crustacea, Brachyura, Majidae). Iheringia Série Zoologia 96(2): 135-140.

Zar, J. H., 1999. Biostatistical Analysis. Pratice-Hall, Upper Saddle River. 